\title{
Amino acid and vitamin supplementation improved health conditions in elderly participants
}

\author{
Masaru Ohtani, ${ }^{1}$ Shigeo Kawada, ${ }^{2,3, *}$ Taizo Seki $^{4}$ and Yasuyuki Okamoto ${ }^{5}$ \\ 'Department of Human and Engineered Environmental Studies, Graduate School of Frontier Sciences, The University of Tokyo, \\ 5-1-5 Kashiwanoha, Kashiwa-shi, Chiba 277-8563, Japan \\ ${ }^{2}$ Laboratory of Tissue Plasticity Science, Department of Life Sciences, Graduate School of Arts and Sciences, The University of Tokyo, \\ 3-8-1 Komaba, Meguro-ku, Tokyo 153-8902, Japan \\ ${ }^{3}$ Future Institute for Sport Sciences, Waseda University, 1-6-1 Nishiwaseda, Shinjuku-ku, Tokyo 169-8050, Japan \\ ${ }^{4}$ Graduate School of Bioagricultural Sciences, Nagoya University, Furo-cho, Chikusa-ku, Nagoya, Aichi 464-8601, Japan \\ ${ }^{5}$ Sansei Hospital, 4-2-5 Kotonoo-cho, Chyuo-ku, Kobe-shi, Hyogo 651-0094, Japan
}

(Received 28 April, 2011; Accepted 10 June, 2011; Published online 5 November, 2011)

\begin{abstract}
The purpose of this study was to investigate the effects of supplementation with amino acids and vitamins on health conditions in unhealthy older people. One bedridden inpatient group ( $n=10$; mean age, $79.8 \pm 8.5 \mathrm{y})$ and one outpatient group $(n=9$; mean age, $72.9 \pm 12.2 \mathrm{y}$ ) participated in this study. A mixture supplementation with amino acids containing arginine $(500 \mathrm{mg} /$ day), glutamine $(600 \mathrm{mg} /$ day $)$, and leucine $(1200 \mathrm{mg} / \mathrm{day})$, and 11 kinds of vitamins was daily administrated for 8 weeks. In both groups, general blood biomarkers such as white blood cell count, natural killer cell activity, and C-reactive protein levels were measured. All measurements were taken before (baseline), at 4 weeks (mid-point), and after each trial (post-point). At mid-point, natural killer cell activity in the outpatient group increased significantly compared to baseline. At post-point, natural killer cell activity in the outpatient and inpatient groups increased significantly compared to baseline. The other blood biomarkers did not show any significant change throughout the trial. This pilot study suggested that a mixture of arginine, glutamine, leucine, and vitamins is useful to support innate immunity in unhealthy older people, even if their diseases, symptoms, and prescribed medicines are different.
\end{abstract}

Key Words: amino acids, immune function, bedridden older inpatients, older outpatients, natural killer cell activity

A s people age, the incidence of age-related health diseases $\mathbf{A}_{\text {such as cerebral infarction, cardiovascular disease, and }}$ diabetes increases. Besides these primary diseases, aging is also associated with attenuation of the immune system..$^{(1,2)}$ While medical care for primary diseases is important, support for the immune system is also required in the elderly patients. Because many of them already take a variety of medicines for their primary diseases, most would prefer not to take more.

Nutritional supplementation with amino acids and vitamins has been shown to affect immune variables. Glutamine and arginine are thought to be good candidates for immune system support. ${ }^{(3,4)}$ Glutamine is the most abundant free amino acid in blood and constitutes more than $50 \%$ of the amino acid pool in human skeletal muscle. Macrophages and lymphocytes contributing to the immune system require glutamine as a fuel. ${ }^{(5)}$ It has been observed that glutamine causes neutrophils to increase their phagocytic activity in a dose-dependent manner. ${ }^{(6)}$ Glutamine is also utilized as a major fuel source by intestinal mucosal cells and influences the gut-associated immune system. ${ }^{(7-9)}$ In an in vitro study, glutamine decreased the tumor necrosis factor $\alpha$-mediated bacterial translocation in enterocytes. ${ }^{(10)}$ Another in vivo study demonstrated that glutamine-supplemented rat group with an obstructed terminal ileum had fewer positive cultures in blood after injection of $E$ coli into the ileal lumen. ${ }^{(11)}$ Although glutamine is not an essential amino acid, it is considered to be a conditionally essential amino acid because its plasma levels decrease sharply when people are critically ill. ${ }^{(12,13)}$ Arginine is also a nonessential amino acid, but has been reported to become conditionally essential in the critically ill. ${ }^{(14,15)}$ It has been observed that arginine prevents thymic involution after surgery and increases the number of lymphocytes. Therefore, it acts as a potent modulator of immune function. ${ }^{(16-18)}$ Several studies have demonstrated that arginine intake improves T-cell activity, neutrophil chemotaxis, and natural killer (NK) cytotoxicity. ${ }^{(4,19-21)}$ Moreover, multivitamin, including vitamin $\mathrm{C}$ and $\mathrm{E}$, is known to improve immunity. ${ }^{(22)}$ It has been observed that various types of diseases such as cancer and hypertension produce reactive oxygen species that impair immune function. ${ }^{(23-25)}$ Therefore, antioxidant effects of vitamins are thought to be beneficial for maintenance of the immune function.

In addition to attenuation of immune function, involuntary loss of muscle mass with aging (sarcopenia) is also a serious problem for maintaining a quality of life. Although resistance exercise programs are recommended for the elderly to prevent sarcopenia, it is difficult for them to engage in these because many of them suffer from multiple diseases. Therefore, nutritional approaches to prevent sarcopenia have been evaluated. It has been observed that leucine, an essential amino acid, activates intracellular kinases linked to the translation of proteins such as those associated with the mammalian target of rapamycin signaling pathway, which includes the 70-kDa ribosomal protein S6 kinase and eukaryotic initiation factor 4E-binding protein 1, leading to stimulation of muscle protein synthesis. ${ }^{(26-29)}$ It has been observed that supplementation with a high proportion of leucine in an oral mixture of essential amino acids resulted in an additional $0.008 \%$ per hour increase in the postprandial muscle protein synthetic rate for $2.5 \mathrm{~h}$ in healthy older men. ${ }^{(30)}$

Based on these studies, we hypothesized that supplementation with a mixture of glutamine, arginine, leucine, and vitamins may have beneficial health effects on the elderly in poor health.

\section{Methods}

Bedridden inpatients. Thirteen bedridden inpatients ( 7 males, 6 females; mean age, $81.8 \pm 8$ years) participated in this study. The hospitalized duration of the bedridden inpatients was $16.4 \pm 7.6$

*To whom correspondence should be addressed.

E-mail: kawada@idaten.c.u-tokyo.ac.jp 
Table 1. Health status and prescription drugs

\begin{tabular}{|c|c|c|c|}
\hline participant & health status & prescription drugs & trial \\
\hline \multicolumn{4}{|c|}{ bedridden inpatients } \\
\hline A & a sequela of brain stem hemorrhage, right gastric cancer & $\begin{array}{l}\text { ranitidine hydrochloride, polaprezinc, theophylline, } \\
\text { carbocysteine, magnesium oxide, pravastatin sodium, } \\
\text { clarithromycin }\end{array}$ & completed \\
\hline B & after septicemia, a sequela of cerebral infarction & $\begin{array}{l}\text { polaprezinc, lactobacilli, sodium ferrous citrate, } \\
\text { brotizolam }\end{array}$ & completed \\
\hline C & a sequela of cerebral infarction & sodium picosulfate hydrate, amlodipine besylate & completed \\
\hline D & a sequela of cerebral infarction, type 2 diabetes & sodium valproate, carbocysteine & completed \\
\hline $\mathrm{E}$ & a sequela of brain hemorrhag & $\begin{array}{l}\text { digoxin, famotidine, brometon, magnesium oxide, } \\
\text { famotidine, lactobacilli }\end{array}$ & completed \\
\hline $\mathrm{F}$ & after acute subdural hematoma & carbocysteine, ranitidine hydrochloride, lactobacilli & dropped out \\
\hline G & $\begin{array}{l}\text { type } 2 \text { diabetes, a sequela of cerebral infarction, } \\
\text { obsolete myocardial infarction }\end{array}$ & nitroglyerin, tiapride hydrochloride, mosapride citrate & completed \\
\hline $\mathrm{H}$ & $\begin{array}{l}\text { obsolete myocardial infarction, chronic respiratory failure, } \\
\text { a sequela of cerebral infarction }\end{array}$ & $\begin{array}{l}\text { aspirin, famotidine, furosemide, magnesium oxide, } \\
\text { ticlopidine hydrochloride, amlodipine besylate, } \\
\text { spironolactone, pravastatin sodium, sennoside, } \\
\text { epinastine hydrochloride, salmeterol xinafoate }\end{array}$ & dropped out \\
\hline I & general prostration, depression, spondylosis deformans & $\begin{array}{l}\text { fluticasone propionate, carbocysteine, } \\
\text { tiotropium bromide hydrate, clarithromycin, sulpiride }\end{array}$ & completed \\
\hline J & $\begin{array}{l}\text { right nephrosclerosis, left ureter cancer, } \\
\text { left brain stem hemorrhage }\end{array}$ & $\begin{array}{l}\text { aspirin, lactobacilli, zopiclone, sodium picosulfate, } \\
\text { proctosedyl }\end{array}$ & completed \\
\hline K & $\begin{array}{l}\text { cerebellar infarction, hypertension, } \\
\text { aspiration pneumonia, reflux esophagitis }\end{array}$ & $\begin{array}{l}\text { lactobacilli, omeprazole, mosapride citrate, } \\
\text { efonidipine hydrochloride }\end{array}$ & dropped out \\
\hline L & $\begin{array}{l}\text { type } 2 \text { diabetes, pressure sore of sacral region, } \\
\text { refractory pneumonia }\end{array}$ & enalapril maleate, aspirin, nizatidine & completed \\
\hline M & malignant lymphoma, chronic gastritis & $\begin{array}{l}\text { sodium valproate, ursodeoxycholic acid, yokukansan, } \\
\text { antibiotic-resistant lactic acid bacteria }\end{array}$ & completed \\
\hline \multicolumn{4}{|l|}{ outpatients } \\
\hline $\mathrm{N}$ & $\begin{array}{l}\text { prostate cancer, a sequela of cerebral infarction, } \\
\text { after implant of pacemaker }\end{array}$ & $\begin{array}{l}\text { amlodipine besylate, ranitidine hydrochloride, } \\
\text { troxipide, pravastatin sodium, zopiclone, furosemide, } \\
\text { magnesium oxide, allopurinol, digoxin, glybenclamide, } \\
\text { aspirin }\end{array}$ & dropped out \\
\hline $\mathrm{O}$ & $\begin{array}{l}\text { angina pectoris, paroxysmal tachycardia, } \\
\text { after surgery of colon cancer, atrial extrasystole }\end{array}$ & $\begin{array}{l}\text { tocopherol nicotinate, dipyridamole, isosorbide dinitrate, } \\
\text { brotizolam, nitroglyerin, sodium ferrous citrate, } \\
\text { zolpidem tartrate }\end{array}$ & completed \\
\hline$P$ & $\begin{array}{l}\text { left ventlicular hypertrophy, anemia after surgery } \\
\text { of gastric cancer, refractory pneumonia }\end{array}$ & $\begin{array}{l}\text { diazepam, fursultiamin, mecobalamin, omeprazole, } \\
\text { polaprezinc, brotizolam, itoprode hydrochloride, } \\
\text { sennoside }\end{array}$ & completed \\
\hline Q & $\begin{array}{l}\text { chronic gastritis, impairment of liver function, } \\
\text { hyperlipemia }\end{array}$ & azulene sulfonate sodium, vitamin B compound & dropped out \\
\hline $\mathrm{R}$ & $\begin{array}{l}\text { hypertension, ventricular extrasystole, } \\
\text { overactive bladder non-neurogenic overactive bladder }\end{array}$ & $\begin{array}{l}\text { tamsulosin hydrochloride, hachimijirogan, } \\
\text { fexofenadine hydrochloride, mexiletine hydrochloride, } \\
\text { valsartan }\end{array}$ & completed \\
\hline s & $\begin{array}{l}\text { type } 2 \text { diabetes, iron deficiency anemia, } \\
\text { diabetic peripheral neuropathy }\end{array}$ & $\begin{array}{l}\text { mecobalamin, valsartan, epalrestat, cilnidipine, } \\
\text { pioglitazone hydrochloride }\end{array}$ & completed \\
\hline $\mathrm{T}$ & $\begin{array}{l}\text { type } 2 \text { diabetes, diabetic nephropathy, } \\
\text { iron deficiency anemia }\end{array}$ & $\begin{array}{l}\text { kalliginogenase, voglibose, fluvastatin sodium, } \\
\text { ranitidine hydrochloride, plaunotol, } \\
\text { difenidol hydrochloride, disopyramide }\end{array}$ & completed \\
\hline$u$ & iron deficiency anemia, hypertension & losartan & completed \\
\hline v & $\begin{array}{l}\text { cerebral infarction, hepatitis type C, liver cirrhosis, } \\
\text { hypertension }\end{array}$ & $\begin{array}{l}\text { aspirin, quinapril hydrochloride, doxazosin mesilate, } \\
\text { enalapril maleate, trichlormethiazide, nifedipine, } \\
\text { ranitidine hydrochloride, troxipide, sennoside, } \\
\text { loratadine }\end{array}$ & completed \\
\hline W & iron deficiency anemia & Not prescripted & completed \\
\hline$x$ & type 2 diabetes, diabetic peripheral neuropathy & $\begin{array}{l}\text { glybenclamide, alfacalcidol, ranitidine hydrochloride, } \\
\text { flurbiprofen, azulene sulfonate sodium }\end{array}$ & completed \\
\hline
\end{tabular}

months. All participants were Japanese; their health status and the prescription drugs they were taking are summarized in Table 1. Eleven of 13 bedridden inpatients underwent percutaneous endoscopic gastrostomy (PEG). Three bedridden inpatients dropped out for the following reasons: 1 (female) had gastritis, 1 (male) had pneumonia, and 1 (male) was moved to another hospital. Doctors confirmed that the causes of discontinuance were not attributed to this trial. 
Table 2. Liquid diet composition/pack (2000 kcal/1000 ml)

\begin{tabular}{|c|c|c|c|c|c|c|c|c|c|}
\hline carbohydrate (g) & 246 & minerals (mg) & & vitamins & & amino acids (g) & & & \\
\hline fat $(g)$ & 86 & potassium & 1496 & vitamin $A(\mu g)$ & 1496.3 & isoleucine & 3.2 & arginine & 2.1 \\
\hline sodium (g) & 0.5 & calcium & 1103 & vitamin B1 (mg) & 4.0 & leucine & 6.0 & glycine & 1.2 \\
\hline dietary fiber (g) & 1.7 & magnesium & 359 & vitamin B2 (mg) & 4.62 & lysine & 5.0 & alanine & 1.9 \\
\hline \multirow[t]{8}{*}{ water } & $700 \mathrm{~mL}$ & phosphorus & 1148 & vitamin B6 (mg) & 5.04 & methionine & 1.8 & serine & 3.7 \\
\hline & & iron & 25.0 & vitamin B12 $(\mu \mathrm{g})$ & 1.0 & cystine & 0.2 & aspartic acid & 4.6 \\
\hline & & zinc & 18.90 & vitamin C (mg) & 349.7 & phenylalanine & 3.4 & glutamate & 14.7 \\
\hline & & copper & 3.0 & vitamin $D(\mu g)$ & 9.98 & tyrosine & 2.7 & proline & 7.2 \\
\hline & & manganese & 0.16 & vitamin $\mathrm{E}(\mathrm{mg})$ & 18.0 & threonine & 2.8 & & \\
\hline & & chlorine & 998 & $\operatorname{niacin}(\mathrm{mg})$ & 53.9 & tryptophan & 0.8 & & \\
\hline & & selenium $(\mu \mathrm{g})$ & 89.8 & folic acid $(\mu \mathrm{g})$ & 399.0 & valine & 4.1 & & \\
\hline & & & & pantothenic acid (mg) & 25.0 & histidine & 2.0 & & \\
\hline
\end{tabular}

Outpatients. Eleven outpatients ( 7 males, 4 females; mean age, $74 \pm 12$ years; body mass index, $21.0 \pm 3.7)$ from the Sansei Hospital (Hyogo Prefecture, Japan) participated in this study. The duration of ambulatory visits to the hospital for the outpatients was $117.6 \pm 64.0$ months. All participants were Japanese; their health status and the prescription drugs they were taking are summarized in Table 1. Two male outpatients dropped out, 1 because of hospitalization (worsening of prostate cancer) and 1 because of a bone fracture. Doctors confirmed that the causes of discontinuance were not attributed to this trial.

Experimental procedures. Administering a placebo to patients as a control group was not agreeable to them and their families. Therefore, in this study we could not set the placebo group. All experimental procedures were performed in accordance with the Declaration of Helsinki. All participants and their families were informed about the experimental procedures and purpose of the study, and they gave written informed consent prior to participation. The ethics committee of the Sansei Hospital approved this study. The duration of this study was 8 weeks.

Diet and supplementation programs for the bedridden inpatients. The bedridden inpatient participants were administered a liquid diet (Isocal 2K, Nestle Nutrition Co., Tokyo, Japan) twice (morning and evening) daily. The composition of the diet is presented in Table 2. The amount of the liquid diet was determined by medical doctors according to the participants' health conditions (mean total calorie, $1147 \pm 334 \mathrm{kcal} /$ day; mean protein intake, $39.0 \pm 11.3 \mathrm{~g} /$ day). A powder containing amino acids and vitamins was mixed in the diet. To avoid malabsorption, the powder was mixed with each of the two daily doses of the liquid diet. The composition of the supplementation is presented in Table 3. This composition was based on our previous studies in which it improved health conditions in young male athletes. ${ }^{(31,32)}$

Diet and supplementation programs for the outpatients. The same amino acid and vitamin supplementation as the inpatients

Table 3. Amino acid and vitamin composition/pack

\begin{tabular}{lclc}
\hline amino acid & $(\mathrm{mg})$ & vitamin & $(\mathrm{mg})$ \\
\hline arginine & 250 & vitamin A & 0.45 \\
glutamine & 300 & vitamin B1 & 1.4 \\
leucine & 600 & vitamin B2 & 1.6 \\
& vitamin B6 & 2.0 \\
& vitamin B12 & 0.004 \\
& vitamin C & 170 \\
& vitamin D & 0.005 \\
& vitamin E & 8.0 \\
& niacinamide & 11.0 \\
& folic acid & 0.4 \\
& pantothenic acid & 5.5 \\
\hline
\end{tabular}

was administered to the outpatients with water twice daily, immediately after dinner and before sleeping. Because they already took a variety of medicines with water for their primary diseases from morning to evening, to avoid satiety, most of them preferred to take the supplementation at evening and before sleep. When the supplementation was administered to the outpatients, they recorded it on a check sheet. The researchers subsequently confirmed the compliance of their supplementation programs. The daily diet of the outpatients was almost the same throughout the trial period except for the additional amino acid and vitamin supplementation. Their habitual nutrient intake was analyzed using food-frequency questionnaires. ${ }^{(33)}$

Anthropometric evaluation. Initially, the outpatient participants were subjected to anthropometric evaluation. The anthropometric evaluation included height, body weight, and body composition comprising fat and lean body mass. Body composition was evaluated by bioimpedance (X-Scan plus, Owa Medical Co., Fukuoka, Japan). This system applies to a constant current of $100 \mu \mathrm{A}$ at $1,5,50,250$, and $550 \mathrm{kHz}$, and $280 \mu \mathrm{A}$ at $1000 \mathrm{kHz}$ thorough the body. Subjects restrained from vigorous exercise and alcohol intake during $24 \mathrm{~h}$, preceding the measurements. The room temperature was kept at $23^{\circ} \mathrm{C}$. Bioimpedance measurements of whole body were theoretically based on a previous study. ${ }^{(34)}$ The participants did not agree to using computed tomography and dual energy X-ray absorptiometry to evaluate body composition owing to concerns of radiation exposure. Anthropometric evaluations were not performed for bedridden inpatients because they faced difficulty in standing.

Blood sampling and measurement of body temperature. Fasting venous blood samples were collected from each subject at least $24 \mathrm{~h}$ before the trial (baseline), on the last day of the 4-week (mid-point) period and on the last day of the 8-week (post-point) period. The body temperature of bedridden inpatients was measured daily. The number of days on which had a fever above $37^{\circ} \mathrm{C}$ was counted and the frequency (febrile frequency, the number of days for which body temperature was more than $37^{\circ} \mathrm{C} /$ the number of days per month $\times 100$ ) was compared with that of control inpatients $(n=11)$ who did not participate in this study but were hospitalized in the same room as the participating inpatients. The control inpatients underwent PEG and were administered the same liquid diet as the inpatient participants (mean total calorie, $1140 \pm 134 \mathrm{kcal} /$ day; mean protein intake, $38.8 \pm 5.0 \mathrm{~g} /$ day).

Blood analyses. Complete blood count and hematocrit were analyzed using an automated hematology analyzer (Coulter Electronics, Hialeah, FL). Concentrations of total plasma proteins, serum albumin, blood urea nitrogen, serum creatinine, and serum amylase activity were determined by routine methods. Serum aspartate aminotransferase, alanine aminotransferase, leucine aminopeptidase, cholinesterase, gamma-glutamyltranspeptidase, and total bilirubin levels were used as liver function markers 
and measured by routine methods. C-reactive protein (CRP) level was used as an inflammation marker and measured using a latex agglutination immunoassay (EIKEN Chemical, Co. Ltd., Tokyo, Japan). To measure the in vitro tumoricidal activity of NK cells, cytotoxicity was measured by determining the amount of ${ }^{51} \mathrm{Cr}$ released from target cells at an effector: target $(\mathrm{E} / \mathrm{T})$ ratio of 20:1. ${ }^{(35)}$ Blood samples were centrifuged at $1500 \times g\left(20^{\circ} \mathrm{C}\right)$ for $20 \mathrm{~min}$ and then $200 \mu \mathrm{L}$ of prepared lymphocyte cells $\left(1 \times 10^{6}\right.$ cells $/ \mathrm{ml}$ ) and $10 \mu \mathrm{L}$ of prepared K562 human chronic myelogenous leukemia cells $\left(1 \times 10^{6}\right.$ cells $\left./ \mathrm{ml}\right)$ labeled with ${ }^{51} \mathrm{Cr}$ were added to a plate. The plate was then incubated for $3.5 \mathrm{~h}$ at $37^{\circ} \mathrm{C}$ in an atmosphere of $5 \% \mathrm{CO}_{2}$. Following incubation, the activity of NK cells was counted using a scintillation counter (Perkin Elmer Japan Co. Ltd., Kanagawa, Japan).

Statistical analysis. The data of dropped out participants were excluded from the data analyses. All data were expressed as mean $\pm \mathrm{SD}$. The differences between the variables were examined by one-way analysis of variance (ANOVA), followed by Fisher's protected least significant difference post-hoc test. Body temperature data were examined using 2 (condition) $\times 2$ (time of measurement) ANOVA for interaction and main effects. When a statistical significance was obtained, Student's $t$ test was used to compare the 2 groups and for comparisons within the same group. Statistical significance was accepted at the $p=0.05$ level.

\section{Results}

The outpatients mean habitual nutrient intake was $34.1 \pm 3.8$ $\mathrm{kcal} / \mathrm{kg} /$ day including $1.27 \pm 0.32 \mathrm{~g}$ protein $/ \mathrm{kg} /$ day. Body weight and body composition in the outpatients did not change throughout the trial (Fig. 1a). At mid-point, NK cell activity in the bedridden inpatients tended to increase compared to baseline $(p=0.08)$, and at post-point, it increased significantly compared to baseline $(p=0.03)$ (Fig. 1b). At mid-point $(p=0.01)$ and postpoint $(p=0.001)$, NK cell activity in the outpatients increased significantly compared to baseline (Fig. 1b). The other biomarkers did not change throughout the trial (Table 4). Febrile frequency in the bedridden inpatients did not change throughout the trial, whereas at the second month in the control inpatients, it increased significantly compared to the first month $(p=0.03)$ (Fig. 2). Febrile frequency did not show a condition $\times$ time interaction.

\section{Discussion}

In this study, we investigated whether supplementation of a combination of glutamine, arginine, leucine, and 11 kinds of vitamins had beneficial effects on the health of older people in poor health. The aging process in humans results in sarcopenia, which involves loss of skeletal muscle mass and function leading to metabolic diseases such as obesity and type 2 diabetes. ${ }^{(36,37)}$ To improve body composition, older outpatients in this study were administered a powder containing leucine because it activates muscle protein synthesis. It has been shown that ingestion of $6.7 \mathrm{~g}$ of essential amino acids containing $2.75 \mathrm{~g}$ of leucine increases muscle protein synthesis (increase of $0.008 \%$ per hour) in younger and older people. ${ }^{(30)}$ The outpatients in this study were each administered $600 \mathrm{mg}$ of leucine immediately after dinner and before sleeping. Because the outpatients had dinner every evening, it was thought that total leucine intake over a short duration in the evenings was at least above $1.2 \mathrm{~g}$. Extrapolation of these data toward the effect of leucine supplementation with dinner for 8 weeks would theoretically result in almost a $0.3 \mathrm{~kg}$ gain in muscle mass. However, an 8-week period of leucine supplementation did not increase lean body mass in the outpatients (Fig. 1a). It has been shown that ingestion of $6.7 \mathrm{~g}$ of essential amino acids containing $2.75 \mathrm{~g}$ of leucine increased muscle protein synthesis, whereas $7.5 \mathrm{~g} /$ day of leucine supplementation for 3 months did not induce any changes in the muscle mass and strength of healthy elderly
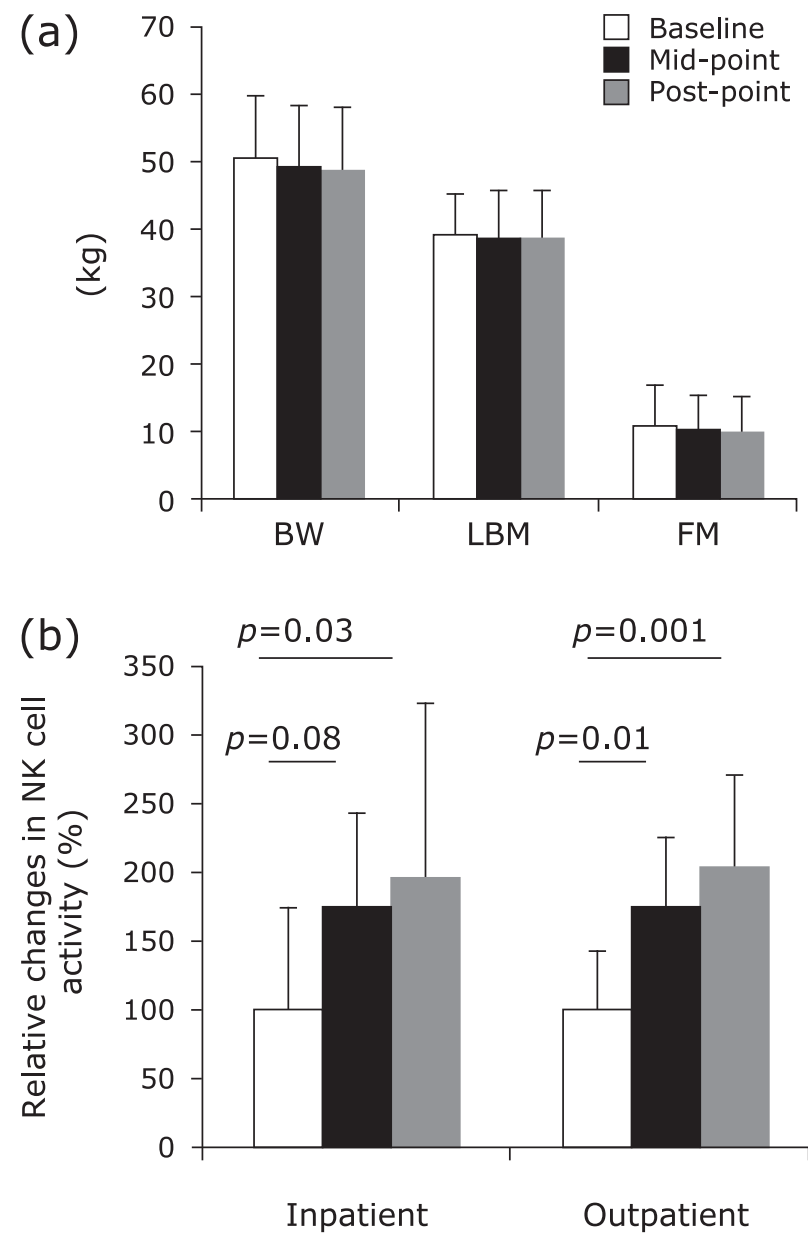

Fig. 1. Changes in body composition (a). Throughout the clinical trial, body weight (BW), lean body mass (LBM), and fat mass (FM) in the outpatients did not change with amino acid and vitamin supplementation. NK cell activity in the inpatient and outpatient groups increased with amino acid and vitamin supplementation (b).

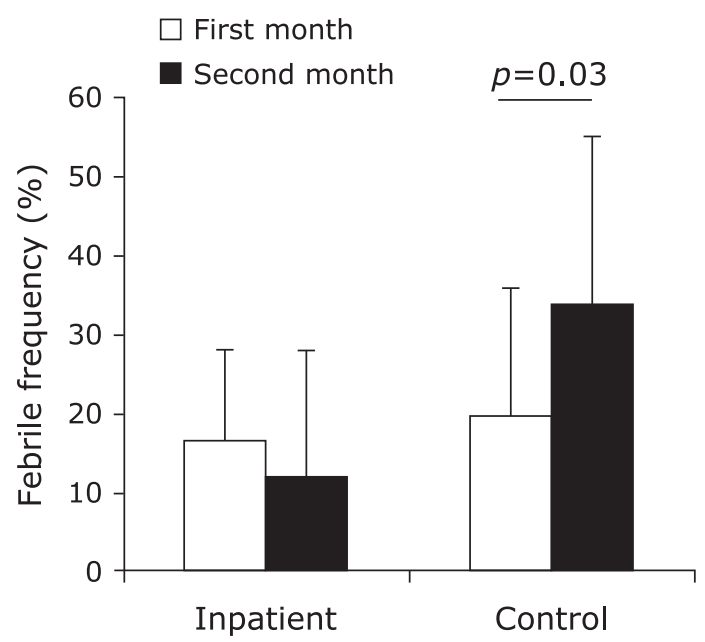

Fig. 2. Febrile frequency (the number of days for which body temperature was more than $37^{\circ} \mathrm{C} /$ the number of days per month $\times 100$ ). 
Table 4. Hematological and biochemical parameters

\begin{tabular}{|c|c|c|c|c|}
\hline & Group & baseline & mid-point & post-point \\
\hline \multirow[t]{2}{*}{ erythrocyte (million/ $\mu l)$} & inpatients & $3.97 \pm 0.74$ & $4.02 \pm 0.63$ & $4.04 \pm 0.59$ \\
\hline & outpatients & $3.97 \pm 0.25$ & $3.89 \pm 0.28$ & $3.87 \pm 0.21$ \\
\hline \multirow[t]{2}{*}{ hemoglobin (g/dl) } & inpatients & $12.22 \pm 2.04$ & $12.37 \pm 1.77$ & $12.52 \pm 1.53$ \\
\hline & outpatients & $11.92 \pm 1.32$ & $11.73 \pm 1.48$ & $11.61 \pm 1.24$ \\
\hline \multirow[t]{2}{*}{$\mathrm{Ht}(\%)$} & inpatients & $38.0 \pm 6.2$ & $38.5 \pm 5.4$ & $38.8 \pm 4.9$ \\
\hline & outpatients & $36.8 \pm 3.2$ & $36.8 \pm 3.5$ & $36.4 \pm 3.0$ \\
\hline \multirow[t]{2}{*}{ platelet (thousand/ $\mu \mathrm{l}$ ) } & inpatients & $243.4 \pm 42.8$ & $240.6 \pm 44.1$ & $248.8 \pm 38.0$ \\
\hline & outpatients & $218.1 \pm 63.9$ & $209.2 \pm 5.87$ & $216.7 \pm 70.5$ \\
\hline \multirow[t]{2}{*}{ leukocyte $(/ \mu \mathrm{l})$} & inpatients & $7320 \pm 1530$ & $7860 \pm 1680$ & $7310 \pm 1290$ \\
\hline & outpatients & $5230 \pm 1260$ & $5120 \pm 1070$ & $4820 \pm 870$ \\
\hline \multirow[t]{2}{*}{ basophilic leukocyte (\%) } & inpatients & $0.50 \pm 0.37$ & $0.63 \pm 0.60$ & $0.67 \pm 0.56$ \\
\hline & outpatients & $0.64 \pm 0.30$ & $0.50 \pm 0.32$ & $0.49 \pm 0.36$ \\
\hline \multirow[t]{2}{*}{ neutrophilic leukocyte (\%) } & inpatients & $52.54 \pm 8.87$ & $57.72 \pm 10.04$ & $54.26 \pm 7.63$ \\
\hline & outpatients & $56.76 \pm 13.47$ & $56.66 \pm 12.52$ & $53.37 \pm 12.86$ \\
\hline \multirow[t]{2}{*}{ acidophilic leukocyte (\%) } & inpatients & $6.11 \pm 7.32$ & $5.88 \pm 7.04$ & $5.97 \pm 6.62$ \\
\hline & outpatients & $2.36 \pm 1.71$ & $2.07 \pm 1.35$ & $2.08 \pm 1.44$ \\
\hline \multirow[t]{2}{*}{ lymphocyte (\%) } & inpatients & $34.30 \pm 4.72$ & $28.36 \pm 5.66$ & $32.51 \pm 5.07$ \\
\hline & outpatients & $33.80 \pm 12.88$ & $34.46 \pm 10.80$ & $36.62 \pm 12.51$ \\
\hline \multirow[t]{2}{*}{ monocyte (\%) } & inpatients & $6.55 \pm 1.95$ & $7.21 \pm 2.28$ & $6.59 \pm 1.40$ \\
\hline & outpatients & $6.44 \pm 1.07$ & $6.32 \pm 1.78$ & $7.44 \pm 2.64$ \\
\hline \multirow[t]{2}{*}{ total plasma protein (g/dl) } & inpatients & $6.98 \pm 0.58$ & $7.01 \pm 0.62$ & $7.07 \pm 0.54$ \\
\hline & outpatients & $7.12 \pm 0.56$ & $7.13 \pm 0.54$ & $7.10 \pm 0.44$ \\
\hline \multirow[t]{2}{*}{ albumin (g/dl) } & inpatients & $3.58 \pm 0.29$ & $3.62 \pm 0.31$ & $3.64 \pm 0.24$ \\
\hline & outpatients & $4.12 \pm 0.23$ & $4.11 \pm 0.34$ & $4.14 \pm 0.29$ \\
\hline \multirow[t]{2}{*}{ total bilirubin (mg/dl) } & inpatients & $0.29 \pm 0.09$ & $0.35 \pm 0.14$ & $0.35 \pm 0.15$ \\
\hline & outpatients & $0.61 \pm 0.23$ & $0.56 \pm 0.13$ & $0.56 \pm 0.11$ \\
\hline \multirow[t]{2}{*}{ aspartate aminotransferase (IU/L) } & inpatients & $28.70 \pm 15.05$ & $36.00 \pm 23.71$ & $23.20 \pm 5.49$ \\
\hline & outpatients & $29.22 \pm 18.98$ & $25.44 \pm 5.29$ & $27.33 \pm 6.56$ \\
\hline \multirow[t]{2}{*}{ alanine aminotransferase (IU/L) } & inpatients & $20.20 \pm 13.81$ & $32.70 \pm 28.28$ & $20.70 \pm 10.09$ \\
\hline & outpatients & $22.78 \pm 21.24$ & $19.11 \pm 6.19$ & $20.33 \pm 8.03$ \\
\hline \multirow[t]{2}{*}{ leucine aminopeptidase (IU/L) } & inpatients & $45.00 \pm 11.05$ & $47.89 \pm 14.15$ & $47.00 \pm 12.76$ \\
\hline & outpatients & $38.89 \pm 5.23$ & $38.67 \pm 4.61$ & $38.89 \pm 2.89$ \\
\hline \multirow[t]{2}{*}{ cholinesterase (IU/L) } & inpatients & $3772 \pm 940$ & $3770 \pm 821$ & $3940 \pm 836$ \\
\hline & outpatients & $3754 \pm 637$ & $3722 \pm 816$ & $3798 \pm 775$ \\
\hline \multirow[t]{2}{*}{ gamma-glutamyltranspeptidase (IU/L) } & inpatients & $30.40 \pm 23.19$ & $38.30 \pm 28.74$ & $35.50 \pm 31.87$ \\
\hline & outpatients & $16.89 \pm 6.47$ & $16.78 \pm 6.94$ & $16.67 \pm 4.61$ \\
\hline \multirow[t]{2}{*}{ blood urea nitrogen (mg/dl) } & inpatients & $21.80 \pm 7.97$ & $22.80 \pm 9.60$ & $23.10 \pm 8.20$ \\
\hline & outpatients & $15.44 \pm 3.97$ & $16.22 \pm 4.89$ & $16.11 \pm 3.37$ \\
\hline \multirow[t]{2}{*}{ serum creatinine $(\mathrm{mg} / \mathrm{dl})$} & inpatients & $0.63 \pm 0.18$ & $0.61 \pm 0.15$ & $0.67 \pm 0.20$ \\
\hline & outpatients & $0.73 \pm 0.18$ & $0.75 \pm 0.21$ & $0.76 \pm 0.21$ \\
\hline \multirow[t]{2}{*}{ serum amylase (IU/L) } & inpatients & $90.90 \pm 33.00$ & $85.80 \pm 32.58$ & $84.40 \pm 31.44$ \\
\hline & outpatients & $97.11 \pm 51.61$ & $97.44 \pm 45.45$ & $100.33 \pm 16.92$ \\
\hline \multirow[t]{2}{*}{ CRP (mg/dl) } & inpatients & $1.02 \pm 1.79$ & $1.18 \pm 1.21$ & $1.38 \pm 2.81$ \\
\hline & outpatients & $0.29 \pm 0.52$ & $0.06 \pm 0.06$ & $0.04 \pm 0.04$ \\
\hline
\end{tabular}

people. ${ }^{(30,38)}$ However, it is thought that muscle protein synthesis is influenced by daily total protein or leucine intake. A daily protein intake above $0.85 \mathrm{~g}$ protein $/ \mathrm{kg}$ body weight is adequate for older people. ${ }^{(39)}$ It has been shown that muscle mass does not increase in subjects whose habitual protein intake is approximately $78 \mathrm{~g} /$ day, even if administered $7.5 \mathrm{~g}$ /day of leucine for 3 months. ${ }^{(38)}$ The outpatients daily protein intake in this study was above $0.85 \mathrm{~g}$ protein $/ \mathrm{kg}$ body weight. Therefore, we can speculate that the outpatients had adequate daily intake of protein and associated leucine. Moreover, the outpatients also had severe diseases. Therefore, their daily physical activity was low, which may have countered the leucine-induced muscle protein synthesis response even if daily intake of protein was adequate and leucine intake increased muscle protein synthesis. To increase muscle mass of older people in poor health, it might be necessary to increase physical activity and leucine intake associated with more physical activity.

Immune parameters were also evaluated in this study. Of these, NK cell activity, an index of innate immunity, increased in the outpatients and inpatients (Fig. 1b). In the immune system, NK cell activity is thought to be one of the important indices for monitoring immunity because innate immunity is the first line of defense against infections. It has been shown that NK cell activity is impaired due to various stressors, such as chronic heart failure ${ }^{(40)}$ 
and high-intensity physical exercise. ${ }^{(41)}$ Moreover, it has been understood that NK cell activity is mediated, at least partially, by nitric oxide-mediated pathways. ${ }^{(42,43)}$ Therefore, it is thought that arginine has a positive effect on NK cell activity because it is the only biosynthetic substrate for nitric oxide. In vitro ${ }^{(42)}$ and in vivo ${ }^{(4)}$ studies have shown that arginine administration enhances NK cell activity. The participants in this study were administered 3 kinds of amino acids. Although the relative efficacy of increased NK cell activity is difficult to estimate, arginine might have been a key factor in this result. The febrile frequency in the control inpatients showed a variation between the first and second halves of the trial, whereas that of the bedridden inpatients was stable throughout (Fig. 2). This result implies that the innate immune system of the inpatients who were administered amino acids was stable due to increased NK cell activity.

Glutamine is the most abundant free amino acid in the human body. It is known to be a conditionally essential amino acid because its plasma levels decrease severely when people are critically ill. ${ }^{(12,13)}$ Nosocomial infections can cause severe clinical problems in older inpatients. To prevent these infections, restoration of immune and gut-barrier functions is important. ${ }^{(44)}$ It has been shown that glutamine supplementation increases lymphocyte count and T-lymphocyte response in surgical patients in addition to improving intestinal immune cell function. ${ }^{(45)}$ In this study, glutamine supplementation did not increase leukocyte, lymphocyte, and monocyte counts (Table 4). Although the participants showed increased NK cell activity, and the febrile frequency of the inpatients was stable, our limited data did not show whether these results were directly or indirectly influenced by glutamine supplementation. Therefore, further research is required to clearly examine the effects of glutamine supplementation on health conditions in older people with poor health.

It has been observed that supplementation with more than $1 \mathrm{~g} /$ day of vitamin C improves immunity in healthy adults. ${ }^{(24)}$ Supplementation with vitamin $E$ in unhealthy subjects $(750 \mathrm{mg} /$ day $)$ and in healthy elderly subjects $(800 \mathrm{mg} /$ day $)$ enhance their immunity. ${ }^{(25,46)}$ The amount of administered vitamins in this study was smaller than that administered in the previous studies. Although the contribution of individual substrates to the increased NK cell activity was not identifiable, it may have partially influenced NK cell activity. This issue should be resolved in future researches.

In conclusion, this study suggested that dietary supplementation with the amino acids arginine $(500 \mathrm{mg} /$ day $)$, glutamine $(600 \mathrm{mg} /$ day), leucine $(1200 \mathrm{mg} /$ day $)$, and 11 kinds of vitamins for the elderly in poor health increased NK cell activity, regardless of the presence of a primary disease and the amount of the daily nutrient intake. This supplementation may be useful for supporting innate immunity and improving the health of these patients.

\section{Acknowledgments}

We are grateful to Junya Omotaka, Sumiko Ozaki, and Rie Miyahara (Sansei Hospital) for recruiting and administrating subjects, and to Fumishige Hinami, MD., Yuichiro Ito, MD., Kouji Sawada, MD., and Toyohiko Tsukano, MD. (Sansei Hospital) for their suggestions about all experimental procedures, and to Kosumo Kouno (Research and Development, Tokiwa Pharmaceutical Co. Ltd.) for performing all blood biomarkers evaluations.

\section{Conflict of Interest}

The authors have declared that no competing interests exist.

\section{Abbreviations}

\section{CRP C-reactive protein}

LBM lean body mass

NK cell natural killer cell

PEG percutaneous endoscopic gastrostomy

\section{References}

1 Fossel M. Cell senescence in human aging and disease. Ann NY Acad Sci 2002; 959: 14-23.

2 Urbán L, Bessenyei B, Márka M, Semsei I. On the role of aging in the etiology of autoimmunity. Gerontology 2002; 48: 179-184.

3 Kuhn KS, Muscaritoli M, Wischmeyer P, Stehle P. Glutamine as indispensable nutrient in oncology: experimental and clinical evidence. Eur J Nutr 2010; 49: 197-210.

4 Moriguti JC, Ferriolli E, Donadi EA, Marchini JS. Effects of arginine supplementation on the humoral and innate immune response of older people. Eur $J$ Clin Nutr 2005; 59: 1362-1366.

5 Bassit RA, Sawada LA, Bacurau RF, Navarro F, Costa Rosa LF. The effect of BCAA supplementation upon the immune response of triathletes. Med Sci Sports Exerc 2000; 32: 1214-1219.

6 Furukawa S, Saito H, Inoue T, et al. Supplemental glutamine augments phagocytosis and reactive oxygen intermediate production by neutrophils and monocytes from postoperative patients in vitro. Nutrition 2000; 16: 323-329.

7 Scheppach W, Loges C, Bartram P, et al. Effect of free glutamine and alanylglutamine dipeptide on mucosal proliferation of the human ileum and colon. Gastroenterology 1994; 107: 429-434.

8 McCauley R, Kong SE, Hall J. Glutamine and nucleotide metabolism within enterocytes. JPEN J Parenter Enteral Nutr 1998; 22: 105-111.

9 Wirén M, Magnusson KE, Larsson J. The role of glutamine, serum and energy factors in growth of enterocyte-like cell lines. Int J Biochem Cell Biol 1998; 30: 1331-1336.

10 Clark EC, Patel SD, Chadwick PR, Warhurst G, Curry A, Carlson GL. Glutamine deprivation facilitates tumour necrosis factor induced bacterial translocation in Caco-2 cells by depletion of enterocyte fuel substrate. Gut 2003; 52: 224-230.

11 Salvalaggio PR, Neto CZ, Tolazzi AR, Gasparetto EL, Coelho JC, Campos AC. Oral glutamine does not prevent bacterial translocation in rats subjected to intestinal obstruction and Escherichia coli challenge but reduces systemic

bacteria spread. Nutrition 2002; 18: 334-337.

12 Planas M, Schwartz S, Arbós MA, Farriol M. Plasma glutamine levels in septic patients. JPEN J Parenter Enteral Nutr 1993; 17: 299-300.

13 Houdijk AP, Rijnsburger ER, Jansen J, et al. Randomised trial of glutamineenriched enteral nutrition on infectious morbidity in patients with multiple trauma. Lancet 1998; 352: 772-776.

14 Morris SM Jr. Recent advances in arginine metabolism. Curr Opin Clin Nutr Metab Care 2004; 7: 45-51.

15 Satriano J. Arginine pathways and the inflammatory response: interregulation of nitric oxide and polyamines: review article. Amino Acids 2004; 26: 321-329.

16 Barbul A, Rettura G, Levenson SM, Seifter E. Arginine: a thymotropic and wound-healing promoting agent. Surg Forum 1977; 28: 101-103.

17 Barbul A, Wasserkrug HL, Yoshimura N, Tao R, Efron G. High arginine levels in intravenous hyperalimentation abrogate post-traumatic immune suppression. J Surg Res 1984; 36: 620-624.

18 Tong BC, Barbul A. Cellular and physiological effects of arginine. Mini Rev Med Chem 2004; 4: 823-832.

19 Efron D, Barbul A. Role of arginine in immunonutrition. $J$ Gastroenterol 2000; 35 Suppl 12: 20-23.

20 Alexander JW. Nutritional pharmacology in surgical patients. Am J Surg 2002; 183: 349-352.

21 Mühling J, Fuchs M, Fleck C, et al. Effects of arginine, L-alanyl-L-glutamine or taurine on neutrophil (PMN) free amino acid profiles and immune function in vitro. Amino Acids 2002; 22: 39-53.

22 High KP. Micronutrient supplementation and immune function in the elderly. Clin Infect Dis 1999; 28: 717-722.

23 Manning RD Jr., Tian N, Meng S. Oxidative stress and antioxidant treatment in hypertension and the associated renal damage. Am J Nephrol 2005; 25: 311-317.

24 Wintergerst ES, Maggini S, Hornig DH. Immune-enhancing role of vitamin 
C and zinc and effect on clinical conditions. Ann Nutr Metab 2006; 50: 85-94.

25 Hanson MG, Ozenci V, Carlsten MC, et al. A short-term dietary supplementation with high doses of vitamin $\mathrm{E}$ increases NK cell cytolytic activity in advanced colorectal cancer patients. Cancer Immunol Immunother 2007; 56: 973-984.

26 Anthony JC, Anthony TG, Kimball SR, Vary TC, Jefferson LS. Orally administered leucine stimulates protein synthesis in skeletal muscle of post absorptive rats in association with increased elF4F formation. $J$ Nutr 2000; 130: $139-145$.

27 Anthony JC, Yoshizawa F, Anthony TG, Vary TC, Jefferson LS, Kimball SR. Leucine stimulates translation initiation in skeletal muscle of postabsorptive rats via a rapamycin-sensitive pathway. J Nutr 2000; 130: 2413-2419.

28 Anthony TG, Anthony JC, Yoshizawa F, Kimball SR, Jefferson LS. Oral administration of leucine stimulates ribosomal protein mRNA translation but not global rates of protein synthesis in the liver of rats. $J$ Nutr 2001; 131: 1171-1176.

29 Rieu I, Balage M, Sornet C, et al. Leucine supplementation improves muscle protein synthesis in elderly men independently of hyperaminoacidaemia. $J$ Physiol 2006; 575: 305-315.

30 Katsanos CS, Kobayashi H, Sheffield-Moore M, Aarsland A, Wolfe RR. A high proportion of leucine is required for optimal stimulation of the rate of muscle protein synthesis by essential amino acids in the elderly. Am J Physiol Endocrinol Metab 2006; 291: E381-E387.

31 Ohtani M, Maruyama K, Sugita M, Kobayashi K. Amino acid supplementation affects hematological and biochemical parameters in elite rugby players. Biosci Biotechnol Biochem 2001; 65: 1970-1976.

32 Ohtani M, Maruyama K, Suzuki S, Sugita M, Kobayashi K. Changes in hematological parameters of athletes after receiving daily dose of a mixture of 12 amino acids for one month during the middle- and long-distance running training. Biosci Biotechnol Biochem 2001; 65: 348-355.

33 Ogawa K, Tsubono Y, Nishino Y, et al. Validation of a food-frequency questionnaire for cohort studies in rural Japan. Public Health Nutr 2003; 6: $147-157$.

34 Ishiguro N, Kanehisa H, Miyatani M, Masuo Y, Fukunaga T. A comparison of three bioelectrical impedance analyses for predicting lean body mass in a population with a large difference in muscularity. Eur J Appl Physiol 2005;
94: $25-35$.

35 Pross HF, Bainies MG, Rubin P, Shragge P, Patterson MS. Spontaneous human lymphocyte-mediated cytotoxicity against tumor target cells. IX. The quantitation of natural killer cell activity. J Clin Immunol 1981; 1: 51-63.

36 Evans WJ. What is sarcopenia? J Gerontol A Biol Sci Med Sci 1995; 50: 5-8.

37 Frontera WR, Hughes VA, Fielding RA, Fiatarone MA, Evans WJ, Roubenoff R. Aging of skeletal muscle: a 12-yr longitudinal study. J Appl Physiol 2000; 88: $1321-1326$

38 Verhoeven S, Vanschoonbeek K, Verdijk LB, et al. Long-term leucine supplementation does not increase muscle mass or strength in healthy elderly men. Am J Clin Nutr 2009; 89: 1468-1475.

39 Campbell WW, Johnson CA, McCabe GP, Carnell NS. Dietary protein requirements of younger and older adults. Am J Clin Nutr 2008; 88: 1322 1329.

40 Yao HC, Liu SQ, Yu K, Zhou M, Wang LX. Interleukin-2 enhances the cytotoxic activity of circulating natural killer cells in patients with chronic heart failure. Heart Vessels 2009; 24: 283-286.

41 Kawada S, Kobayashi K, Ohtani M, Fukusaki C. Cystine and theanine supplementation restores high-intensity resistance exercised-induced attenuation of natural killer cell activity in well-trained men. $J$ Strength Cond Res 2010; 24: 846-851.

42 Jyothi MD, Khar A. Induction of nitric oxide production by natural killer cells: its role in tumor cell death. Nitric Oxide 1999; 3: 409-418.

43 Nieves C Jr., Langkamp-Henken B. Arginine and immunity: a unique perspective. Biomed Pharmacother 2002; 56: 471-482.

44 Conejero R, Bonet A, Grau T, et al. Effect of a glutamine-enriched enteral diet on intestinal permeability and infectious morbidity at 28 days in critically ill patients with systemic inflammatory response syndrome: a randomized, single-blind, prospective, multicenter study. Nutrition 2002; 18: 716-721.

45 Van der Hulst RR, Von Meyenfeldt MF, Tiebosch A, Buurman WA, Soeters PB. Glutamine and intestinal immune cells in humans. JPEN J Parenter Enteral Nutr 1997; 21: 310-315.

46 Meydani SN, Barklund MP, Liu S, et al. Vitamin E supplementation enhances cell-mediated immunity in healthy elderly subjects. Am J Clin Nutr 1990; 52: $557-563$. 